ORIGINAL ARTICLE

\title{
Quality of Life for Indian Diabetic Children
}

\author{
Rakesh Kumar $^{1}$, Jyoti Patodia ${ }^{2}$, Prahbhjot Malhi ${ }^{3}$, Devi Dayal ${ }^{4}$
}

\begin{abstract}
Introduction: Type 1 diabetes mellitus (T1DM) is a chronic disease requiring complex management including blood glucose monitoring, insulin administration along with diet restrictions which can have a negative impact on the quality of life (QoL) of children.

Objective: To assess the quality of life and factors affecting it in Indian children with T1DM.

Materials and methods: A cross-sectional study was conducted on 97 children (4-15 years) with T1DM diagnosed for at least 6 months, at the pediatric diabetes clinic of a tertiary care hospital. QoL was assessed using the "quality of life instrument in Indian diabetics" (QOLID) questionnaire. The further co-relation between the QOLID scores and various demographic and diabetes-related factors were studied.

Results: There was suboptimal glycemic control ( $\mathrm{HbA1c}>7.5 \%)$ in $76 \%$ of our patients. The mean total QOLID score was $84.5 \%$ which was significantly low in specific domains like general health (71\%), diet satisfaction (74\%) and financial worries (75\%). Eighteen percent (18\%) of patients had overall impaired QoL (total QOLID score $<80 \%$ ), highest seen in the domain of general health (72\%). There was a strong negative correlation between the total QOLID score and variables like number of hyperglycemic episodes per month $(r=-0.3, p=0.001)$, the total number of hospitalizations $(r=-0.34, p=0.001)$ and $\mathrm{HbA1}$ c value over last 6 months $(r=-0.38, p=0.0001)$

Conclusion: As assessed by QOLID questionnaire, impaired QoL was seen in 18\% of Indian children with T1DM. Poor glycemic control and an increased number of hospitalizations were the two most important factors leading to poor QoL.

Clinical significance: The overall outcome of diabetes in children can be improved by improving their QoL which further depends on good glycemic control.

Keywords: Cross-sectional study, Indian children, Quality of life, Quality of life instrument in Indian diabetics questionnaire.

Journal of Postgraduate Medicine, Education and Research (2019): 10.5005/jp-journals-10028-1314
\end{abstract}

\section{INTRODUCTION}

\section{Type 1 Diabetes Mellitus}

Type 1 diabetes mellitus (T1DM) is one of the common chronic childhood illnesses, affecting approximately 1 in every 400-600 children and adolescents worldwide. ${ }^{1}$ T1DM, being a chronic disease, affects the lifestyle of the diseased in different ways. Treatment of T1DM consists of multiple daily insulin injections along with frequent self-monitoring of blood glucose (SMBG) by multiple finger pricks in a day and adjusting/restricting food intake, physical exercise, and/or the amount of insulin administered. This stringent routine can be quite stressful for the patient. Patients with T1DM experience fluctuations ranging from hyperglycemia to hypoglycemia, the acute and chronic effects of which can interfere with daily activities. ${ }^{2}$ Thus T1DM affects a child's physical, mental and psychosocial function which impacts the QoL.

QoL is now recognized as an important outcome for people with diabetes. It is a multidimensional concept which describes the physical, social and psychological aspects of well-being and functioning. ${ }^{3}$ The term 'health-related quality of life' (HRQOL) narrows QoL to aspects relevant to health. In general, diabetes has been shown to impact QoL negatively. Indeed, there is considerable evidence that children and adolescents with T1DM experience poorer HRQOL in comparison to healthy peers. ${ }^{4}$

In India, very few studies have been conducted on QoL in diabetes, out of which most of them are in adults (type $2 \mathrm{DM}$ ). The literature on QoL in Indian children with T1DM is very scarce. Due to differences in health care delivery system, family relationships, attitude and awareness of diabetes in Indian sub-continent there was a need for more studies in this part of the world especially in children where stringent food habits and multiple pricks can

\author{
${ }^{1,3,4}$ Professor, ${ }^{2}$ Resident \\ ${ }^{1-4}$ Department of Pediatrics, Postgraduate Institute of Medical \\ Education and Research, Chandigarh, India
}

Corresponding Author: Jyoti Patodia, Resident, Department of Pediatrics, Postgraduate Institute of Medical Education and Research, Chandigarh, India, e-mail: jyoti_ag7@hot mail.com

How to cite this article: Kumar R, Patodia J, Malhi P, Dayal D. Quality of Life for Indian Diabetic Children. J Postgrad Med Edu Res 2019; 53(2):61-68.

Source of support: Nil

Conflict of interest: None

significantly affect their QoL. In India, there are very few specialized centers, including our center, taking care of such children which however, do not focus much on the psychosocial aspect as it is not considered to be so important. Further, most of the parents are not literate enough to understand home management of insulin and blood glucose which is also complicated by financial constraints. Thus, the stress of maintaining normal glucose with minimal resources and support along with diet restriction and multiple pricks may predispose these children to have a negative impact on QoL. Keeping this in mind, the present study aimed to assess the QoL and to study their correlates in our cohort of children with type 1 DM using the QOLID instrument ${ }^{5}$ specially designed for the Indian population.

\section{Materials and methods Study Design and Setting}

A cross-sectional study was conducted over one year from January 2012-December 2012.

(C) The Author(s). 2019 Open Access This article is distributed under the terms of the Creative Commons Attribution 4.0 International License (https://creativecommons. org/licenses/by-nc/4.0/), which permits unrestricted use, distribution, and non-commercial reproduction in any medium, provided you give appropriate credit to the original author(s) and the source, provide a link to the Creative Commons license, and indicate if changes were made. The Creative Commons Public Domain Dedication waiver (http://creativecommons.org/publicdomain/zero/1.0/) applies to the data made available in this article, unless otherwise stated. 


\section{Setting}

Pediatric Diabetes Clinic, Advanced Pediatric centre, Tertiary care hospital.

\section{Study Population}

Children between 4-15 years of age of either sex, diagnosed as T1DM at least 6 months before the study, who were on regular follow up in our pediatric diabetes clinic, were enrolled. Children with concomitant neurological disease, psychiatric illness or any other systemic/chronic illness were excluded.

\section{Ethical Clearance}

Institute's ethics committee approved the study.

\section{Study Procedures}

Written informed consent was taken (and accent from older children) from the primary caretaker/guardian of children and adolescents with T1DM before enrollment in the study. All the children attending the pediatric diabetes clinic fulfilling the inclusion criteria and willing to participate in the study were enrolled. The primary caregiver was interviewed to obtain information regarding the demographic profile and other information like metabolic control, dietary habits (number of daily meals, snacks) and socioeconomic status (SES) of the family was collected from the diabetes log book and hospital follow-up record.

QoL was measured using the QOLID questionnaire ${ }^{5}$ which was translated into Hindi with some minor modifications in the questionnaire according to the pediatric population as it was originally designed for the adult population. The survey took approximately 10 minutes to complete. The questionnaire was directly asked the children above 10 years of age, and for children below 10 years of age, the questionnaire was asked to the parents.

\section{Tools}

\section{Quality of Life Instrument for Indian Diabetes Patients}

This instrument is the first reliable, validated and sensitive tool for health-related and diabetes-specific assessment of the quality of life in Indian patients with type 2 diabetes developed by Nagpal et al. ${ }^{5}$ It takes only 7.8 (SD 2.4) minutes to complete and hence it can be used during routine physician consultation. It consists of 34 items covering eight domains which cover different aspects of quality of life namely role limitations due to physical health, physical endurance, general health, treatment satisfaction, symptom frequency, financial worries, mental health, and diet advice satisfaction. All these domains and items had high internal consistency (Cronbach's alpha of 0.894). There is the use of a standard Likert scale across all questions. Questions are scored from 1 to 5 ; lower scores indicated poorer QoL and higher scores indicating higher QoL. The total maximum score was 170 . The domains and items relating to general health, role limitation due to physical health and physical endurance were classified as HRQOL while all other domains reflect disease-specific QoL. A score for each domain was calculated by the simple addition of item score. Each domain score was then standardized by dividing by maximum possible domain score and multiplying by 100 . All individual standardized domain scores were then added and divided by 8 (number of the domain) to obtain an overall score. As QOLID questionnaire is mainly designed for Indian adult Diabetic patients, and it is being used for the first time in the pediatric population, to validate it, sensitivity and specificity were evaluated by ROC curve. According to which, the value at which QOLID had maximum sensitivity and specificity for a better QoL was at a score of $>140$ (i.e., $80 \%$ ) at which sensitivity is $78 \%$, and specificity is $65 \%$. Thus taking the 50th percentile (140) of QOLID score, along with value obtained by ROC curve (140), we took $80 \%$ as cut off to divide our patients into two groups, such as those $<80 \%$ were considered to have impaired QoL and those having the score $>80 \%$ had a better QoL. The QOLID instrument was initially designed in English. A forward translation did a Hindi translation from English to Hindi followed by an independent backward translation into English which was found to be similar. We applied the questionnaire in bilingual format (English and Hindi) on our patients. Some minor changes were made according to the pediatric population, such as, 'You' was replaced by 'your child', 'work' was replaced by 'school/ school activities' and activities like 'working/driving' was replaced by 'studying/playing,' e.g., how often do you miss your work because of your diabetes? was modified as 'how often your child misses his/ her school because of diabetes?

\section{Sample Size}

To find proportion of children with T1DM with impaired quality of life, considering anticipated proportion $(\mathrm{P})$ to be $10 \%$, acceptable margin of error (e) $6 \%$, confidence interval $90 \%$, width of $10 \%$ and a-level of significance being 5\%; using the formula $\left(n=Z a^{2} \times P Q / e^{2}\right)$ sample size ( $n$ ) calculated was 96 (Za is level of confidence, 1.96 for 2-sided/2 tailed test, $Q=1-P$, i.e., Proportion of subjects without the disease).

\section{Statistical Analysis}

Preliminary analysis was descriptively expressed as means (SD), medians (range), proportions and frequencies. Children identified with low QOLID scores $(<80)$ were compared with those with higher scores (>80). For parametric data, Chi-square/Fisher exact test was applied. The $p$ value of less than 0.05 was taken as statistically significant. Correlation between QOLID score with different demographic and diabetes-specific variables was explored using Pearson's coefficients. Data were further analyzed using multiple linear regression analysis. The analysis was done using the statistical package for social sciences (SPSS) version 20.0 for Windows.

\section{ResUlts}

A total of 97 patients including 59 (61\%) males and 38 (39\%) females with a mean age of $9.6 \pm 2.69$ years (range $5-15$ years) were enrolled in the study. Mean age of onset of T1DM was 7.2 years (range 1.5-12.8 years) and the average duration of T1DM was 2 years, with a majority of them (46\%) having duration less than 2 years. Forty-eight percent (48\%) of children belonged to lower socioeconomic status as per modified Kuppuswamy scale which takes parents education, income, and occupation into consideration. Sixty-one percent (61\%) of children belonged to nuclear families, and only $4 \%$ had single/ separated parents. Six percent (6\%) had associated autoimmune hypothyroidism, and $11 \%$ had celiac disease. Diabetes-related data of enrolled patients are given below in Table 1.

The mean $\mathrm{HbA} 1 \mathrm{c}$ of our patients was $12.3 \% \pm 2.16$ at the time of diagnosis and $9.1 \% \pm 2.08$ over last 6 months; $24 \%$ had optimal glycemic control ( $\mathrm{HbA} 1 \mathrm{c}<7.5 \%)$ and $76 \%$ had suboptimal glycemic values $(\mathrm{HbA} 1 \mathrm{c}>7.5 \%)$ as per the latest ADA guidelines for children at this age ${ }^{6}$ Nearly three-fourths of patients (72\%) were using premixed (regular/NPH:30/70) insulin in morning and evening with regular insulin shot pre-lunch (3 injections regimen). The mean dose of insulin was $0.86 \mathrm{U} / \mathrm{kg} /$ day and at least three times blood glucose monitoringBGM () was done in $37 \%$. Twenty percent were doing, and $25 \%$ had lipodystrophy. 
Table 1: T1DM related parameters of enrolled children $(n=97)$

\begin{tabular}{ll}
\hline & $\begin{array}{l}\text { Mean (S.D) } \\
\text { no. of } \\
\text { patients (\%) }\end{array}$ \\
\hline Age of onset of diabetes (years) & $7.2( \pm 2.86)$ \\
Onset <5years & $30(31 \%)$ \\
Onset $>5$ years & $67(69 \%)$ \\
Duration of diabetes (years) & $2.41( \pm 1.49)$ \\
$<2$ years & $44(45.5 \%)$ \\
$2-4$ years & $36(37.1 \%)$ \\
$>4$ years & $17(17.5 \%)$ \\
\hline Total number of DKA episodes & \\
None & $57(59 \%)$ \\
One & $35(36 \%)$ \\
Two & $4(5 \%)$ \\
Total number of DKA episodes in last 6 months & \\
None & $91(94 \%)$ \\
One & $5(5.2 \%)$ \\
Two & $1(1 \%)$ \\
No. of hyperglycemic episodes/month $(>200 \mathrm{mg} / \mathrm{dL})$ & $11.6( \pm 8.3)$ \\
No. of hypoglycemic episodes/month $(<60 \mathrm{mg} / \mathrm{dL})$ & $3.6( \pm 2.4)$ \\
\hline
\end{tabular}

\section{QOLID Scores}

The mean total score of QoL in our patients was $84.1 \%$ (143). The mean score was significantly low in specific domains like general health (71\%), diet satisfaction (74\%) and financial worries (75\%). Mean QOLID scores in its various domains are given in Table 2. Seventeen (18\%) of a total of 97 patients had overall impaired QoL (i.e., total QOLID score $<80 \%$ ). Most $(72 \%)$ of our patients had impaired QoL in the domain of general health. Similarly about half of our patients, i.e., $51 \%$ and $49 \%$ had poor QoL in domains of financial worries and diet satisfaction respectively and almost one-fourth scored low in domains of treatment satisfaction and symptom botherness, as depicted in Graph 1.

The study showed a strong correlation between the total QOLID score and variables like a number of hyperglycemic episodes per

Table 2: Mean total QOLID scores and mean QOLID scores for various domains in children with T1DM

\begin{tabular}{ll}
\hline Domains & Mean $(\%)(S D)$ \\
\hline QOLID 1 (role limitation) & $93.6( \pm 10.1)$ \\
QOLID2 (physical endurance) & $96.2( \pm 5.5)$ \\
QOLID3 (general health) & $70.6( \pm 10.4)$ \\
QOLID4 (treatment satisfaction) & $84.4( \pm 16.3)$ \\
QOLID5 (symptom botherness) & $81.1( \pm 10.0)$ \\
QOLID6 (financial worries) & $74.7( \pm 19.6)$ \\
QOLID7 (emotional/mental health) & $84.5( \pm 9.7)$ \\
QOLID8 (diet satisfaction) & $73.6( \pm 10.7)$ \\
\hline Total QOLID & $84.1( \pm 6.88)$ \\
\hline
\end{tabular}

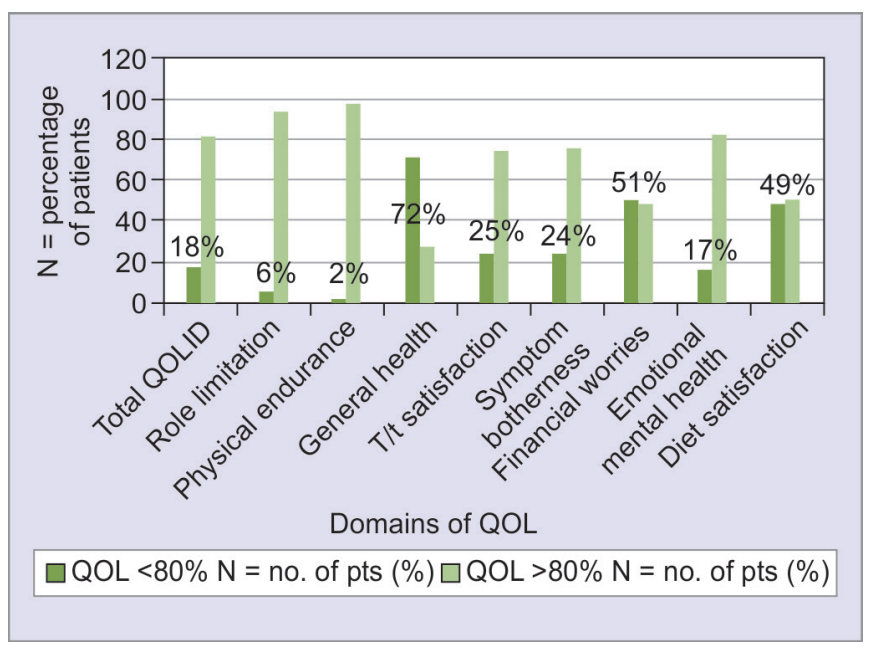

Graph 1: Impaired QoL (QoL <80\%) in enrolled children with T1DM in various domains $(n=97)$

month, the total number of hospitalizations and over last 6 months, $\mathrm{HbA1} \mathrm{c}$ value at the time of diagnosis and over last 6 months. HbA1c over the last 6 months had the strongest negative correlation with QOLID score, i.e., higher the value of $\mathrm{HbA1c}$ lower will be the QoL $(r=-0.379, p=0.000)$. Correlation between total QOLID scores and different sociodemographic and diabetes-specific variables is given below in Table 3.

A stepwise multiple linear regression analysis was done where the total QOLID score was taken as the dependent variable as given in Table 4. HbA1c (in last 6 months), number of hospitalization in last 6 months and hyperglycemic episodes per month were significant independent predictors in determining QoL score of our diabetic children. HbA1c independently effected QOLID score the most $(p=0.009 ; \mathrm{Cl}-2.7,-0.4)$, with coefficient of correlation $(\beta)=-0.28$. Thus, glycemic control is the single most significant independent predictor in determining QoL.

\section{Discussion}

The mean total QOLID score of our patients was 84.1\%, and QoL was mainly impaired in specific domains like general health (71\%), diet satisfaction (74\%) and financial worries (75\%) as suggested by their mean QOLID scores. Our study showed that $18 \%$ of children with T1DM had impaired QoL. Whereas concerning specific domain, $72 \%$ had impaired QoL in general health, about half of them had poor QoL in domains of financial worries and diet satisfaction and nearly one-fourth scored low in domains of treatment satisfaction and symptom botherness.

Studies done in the West showed similar results. According to a study in the Italian population by Ausili et al. in diabetic children, the domain of general health was negatively impacted by Diabetes which was mainly influenced by the metabolic picture. ${ }^{7}$ A recent study was done in Kuwait ${ }^{8}$ using the PedsQL 4.0 generic core scale and PedsQL 3.0 diabetes module also showed that the HRQoL of children and adolescents with T1DM was consistently poorer than controls. Authors also reported that higher $\mathrm{HbA1c}$ values were associated with lower QoL scores. ${ }^{9}$ However, some studies have suggested that children and youth with type 1 diabetes perceived similar levels of HRQOL as their healthy peers. ${ }^{10}$ This was probably due to good resources in terms of treatment, education and social services.

Our study suggested that $\mathrm{HbA1c}$ in the last 6 months was the strongest factor associated with QOLID score, i.e., higher the 
Table 3: Correlation between total QOLID scores and sociodemographic and T1DM specific variables

\begin{tabular}{lll}
\hline $\begin{array}{l}\text { Sociodemographic and diabetes specific } \\
\text { variables }\end{array}$ & \multicolumn{2}{c}{ Total QOLID score } \\
\hline & Correlation $(r)$ & $p$ value \\
\hline Age & -0.023 & 0.825 \\
Sex & 0.057 & 0.577 \\
Socioeconomic status & -0.198 & 0.052 \\
Age of onset & -0.039 & 0.705 \\
Duration of diabetes & 0.029 & 0.780 \\
Hyperglycemic episodes per month & -0.332 & 0.001 \\
Hypoglycemic episodes per month & -0.197 & 0.053 \\
Total hospital admissions & -0.342 & 0.001 \\
Total hospital admissions in 6 months & -0.321 & 0.001 \\
Total DKA episodes & -0.145 & 0.156 \\
Total DKA episodes in last 6 months & -0.118 & 0.250 \\
HbA1c at the time of diagnosis & -0.225 & 0.027 \\
HbA1c in last 6 months & -0.379 & 0.000 \\
Comorbidities (celiac, hypothyroidism) & -0.134 & 0.191 \\
\hline
\end{tabular}

value of $\mathrm{HbA1c}$, lower will be the QoL $(r=-0.379$ and $p=0.000)$. Similarly higher the number of hyperglycemic episodes per month and hospital admissions, more unfortunate was the QoL. Also metabolic control ( $\mathrm{HbA1c}$ ) in last 6 months, hospital admission in last 6 months and hyperglycemic episodes per month were significant independent predictors of quality of life in our patients, out of which, glycemic control in last 6 months was the strongest predictor. A study by Hoey et al., ${ }^{11}$ a large multicentric study also suggested that lower $\mathrm{HbA1c}$ was associated with lower impact ( $p<0.0001)$, fewer worries $(p<0.05)$, greater satisfaction $(p<0.0001)$, and better health perception $(p<0.0001)$ for adolescents. The Hvidore study group, ${ }^{12}$ also showed that good adolescent QoL was associated with better metabolic control. Results of the study suggested that adolescents living with one parent had a significantly higher $\mathrm{HbA} 1 \mathrm{c}(9.0 \%$, $\mathrm{n}=298, p<0.001)$ than those living with two parents $(8.6 \%, \mathrm{n}=1530)$.

Results of our study showed that variables like age, sex, socioeconomic status, age at onset and duration of diabetes, number of hypoglycemic episodes per month, total number of DKA episodes, family type (nuclear/joint), type and amount of insulin injections and its dose, frequency of blood glucose monitoring and associated co-morbidities like celiac and hypothyroidism did not have any significant effect on the QoL of our patients.

In contrast to our study, there is some evidence that quality of life is lower in girls and youths with shorter disease duration. A study by Grey et al. found the lower quality of life was associated with lower socioeconomic status. ${ }^{13}$ A study by Wagner et al. pointed to age-related differences that may help explain deteriorating glycemic control during adolescence. ${ }^{14}$ A study by Kalvya et al. in Greek children indicated that later age of onset of diabetes, less hyperglycemic episodes, lower glycosylated hemoglobin (HbA1c), older age, and male gender were associated with better HRQOL in diabetes. ${ }^{15}$

However, some studies have also shown results similar to ours. A survey by Vanelli et al. conducted in Italian population revealed that the impact of diabetes was similar for both boys and girls with no effect regarding age or the duration of diabetes, but the
Table 4: Regression analysis of different variables on quality of life determined by total QOLID scores in enrolled children with T1DM

\begin{tabular}{lllll}
\hline & $\begin{array}{l}\text { B (co-efficient of } \\
\text { correlation) }\end{array}$ & Sig. ( $p$ ) & \multicolumn{2}{c}{$95 \% \mathrm{Cl}$} \\
\hline & & & $\mathrm{LL}$ & $\mathrm{UL}$ \\
\hline $\begin{array}{l}\text { Hyperglycemia/ } \\
\text { month }\end{array}$ & -0.33 & 0.001 & -0.74 & -0.19 \\
$\begin{array}{l}\text { HbA1c at diagnosis } \\
\text { HbA1c( last 6 }\end{array}$ & -0.03 & 0.80 & -1.26 & 0.98 \\
$\begin{array}{l}\text { months) } \\
\text { DKA (6 months) }\end{array}$ & -0.28 & 0.009 & -2.72 & -0.40 \\
$\begin{array}{l}\text { DKA (total) } \\
\text { Hospitalizations (6 }\end{array}$ & -0.012 & 0.073 & -1.04 & 22.94 \\
$\begin{array}{l}\text { months) } \\
\text { Hospitalization } \\
\text { (Total) }\end{array}$ & -0.207 & 0.911 & -4.31 & 3.85 \\
\hline
\end{tabular}

* Dependent variable: Total QOLID score

influence of $\mathrm{HbA} 1 \mathrm{c}$ values was significant $(p<0.001) .{ }^{16}$ A study by Ingerski et al. demonstrated that adolescents achieving lower HbA1c levels had increased SMBG frequency which can occur without the expense of diminished QoL. ${ }^{17}$ In our study, it was seen that most of the patients (45\%) had an inadequate frequency of SMBG, but did not have any impact on QoL, nor did it affect much on the glycemic control of our patients.

A recent study by Puri et al. suggested that nearly one-third of patients had an adverse effect on their QoL due to their diabetes which is quite high as compared to our study. Early onset of diabetes (before age 5 years) was associated with a significantly lesser negative impact on the overall QoL score. However, in our study, we did not find any significant association between age of onset of T1DM and QoL. Also in contrast to our research, there was no significant association of poor glycemic control with the overall QoL score, which is the strongest predictor of QoL amongst our study group. ${ }^{18}$ This overall difference in our study reflects probably a better understanding of the disease among our patients due to the difference in education and counseling.

Thus, it is encouraging to know that despite limited healthcare resources, low SES and financial constraints, in the present study, only $18 \%$ children with T1DM had impaired QoL, the magnitude, and severity of which seems to be less as compared to the numerous studies done in other developed countries. This could be attributed to the fact that most of the studies done in the past have targeted the adolescent age group which is supposed to be the most vulnerable group, whereas we have taken a broad age range of subjects (4-15 years). Also, Indian patients probably have a good support system in the form of family and peers and probably have better-coping abilities. Around $40 \%$ of our patients were residing in joint families with $96 \%$ having both parents along, which is quite different from the situation in the west. These results may apply to all children with T1DM in developing countries who receive care and treatment in similar settings.

There are exceptionally few limited studies in India regarding QoL in children with T1DM; hence this study would provide some more light into this aspect of diabetic care in Indian children. The study population is representative of the target population in developing countries with inadequate resources; hence results apply to the rest of the diabetic children in developing countries as well. Further, the questionnaire used in the study is a wellvalidated standardized questionnaire mainly designed for the 
Indian population. Also, we have translated the questionnaire in Hindi as well considering our study population, where Hindi is the main spoken language. However, there are certain limitations to our study. Firstly, no controls were taken in the present study. Secondly, the QOLID questionnaire is actually designed for Indian adults with Diabetes. But, we wanted to use this questionnaire as it is more specific and validated in the Indian population. However, we have modified a few questions according to the pediatric age group keeping its originality intact. It needs to be further validated in the pediatric age group as well, and this study is the preliminary step in the process of validation.

To conclude, $18 \%$ of Indian children with T1DM had impaired QoL which was relatively lesser compared to most of the western studies. Most of our patients had impaired QoL in domains of general health (72\%), followed by diet satisfaction (49\%) and financial worries (51\%). Disease-related factors like glycemic control and number of hospitalizations were most essential determinants, whereas other sociodemographic factors did not have a significant impact on QoL. Thus, our study highlights the importance of reasonable diabetic control for better QoL and vice versa. Assessment of QoL should be done periodically in such children so that if any significant impairment is identified, early interventions could be initiated and thus improve the overall outcome of the disease.

\section{Clinical significance}

The overall outcome of diabetes in children can be improved by improving their $\mathrm{QOL}$ which further depends on good glycemic control.

\begin{tabular}{l}
\hline Key message \\
\hline Children and adolescents with T1DM have less impaired QoL in \\
Indian subcontinent as compared to other developed countries \\
despite limited resources, illiteracy and financial constraints. \\
\hline Poor glycemic control does remain the most important factor \\
affecting the QoL in Indian children with diabetes. \\
\hline
\end{tabular}

\section{References}

1. Diabetes in the young in International Diabetes Federation.IDF Diabetes Atlas.5th edition. Brussels, Belgium: International Diabetes Federation; 2011.http://www.idf.org/diabetesatlas.

2. Nordfeldt S, Ludvigsson J. Fear and other disturbances of severe hypoglycaemia in children and adolescents with type 1 diabetes mellitus. J Pediatr Endocrinol Metab 2005; 8(1):83-91.
3. Calman K. Definitions and dimensions of quality of life in: The Quality of Life of Cancer Patients. Raven Press New York 1987:81-97.

4. Cameron FJ. The impact of diabetes on health-related quality of life in children and adolescents. Pediatr Diabetes. 2003;4(3):132-136.

5. Nagpal J, Kumar A, Kakar S, et al. The development of 'Quality of Life Instrument for Indian Diabetes patients (QOLID): a validation and reliability study in middle and higher income groups. J Assoc Physicians India 2010;58:295-304.

6. American Diabetes Association. Standards of medical care in diabetes-2015. Diabetes Care 2015;38(Suppl 1):S1-S93.

7. Ausili E, Tabacco F, Focarelli B, et al. Multidimensional study on quality of life in children with type 1 diabetes. Eur Rev Med Pharmacol Sci 2007;11(4):249-255.

8. Abdul-Rasoul M, Alotaibi F, Abdulla A, et al. Quality of Life of Children and Adolescents with Type 1 Diabetes in Kuwait. Med Princ Pract 2013;22:379-384.

9. Laffel LM, Connell A, Vangsness L, et al. General quality of life in youth with type 1 diabetes: relationship to patient management and diabetes-specific family conflict. Diabetes Care 2003;26(11): 3067-3073.

10. Wagner VM, Muller-Godeffroy E, Von Sengbusch S, et al. Age, metabolic control and type of insulin regime influences healthrelated quality of life in children and adolescents with type 1 diabetes mellitus. Eur J Pediatr 2005;164(8):491-496.

11. Hoey H, Aanstoot HJ, Chiarelli F, et al. Good metabolic control is associated with better quality of life in 2,101 adolescents with type 1 diabetes. Diabetes Care 2001;24(11):1923-1928.

12. Hoey H. Psychosocial factors are associated with metabolic control in adolescents: research from the Hvidore Study Group on Childhood Diabetes. Pediatr Diabetes 2009;10(Suppl 13):9-14.

13. Grey M, Boland EA, Yu C, et al. Personal and family factors associated with quality of life in adolescents with diabetes. Diabetes Care 1998; 21(6):909-914.

14. Wagner JA, Abbott $G$, Lett $S$. Age related differences in individual quality of life domains in youth with type 1 diabetes. Health Qual Life Outcomes 2004;2:54.

15. Kalyva E, Malakonaki E, Eiser C, et al. Health-related quality of life (HRQoL) of children with type 1 diabetes mellitus (T1DM): self and parental perceptions. Pediatr Diabetes 2011;12(1):34-40.

16. Vanelli M, Chiarelli F, Chiari G, et al. Relationship between metabolic control and quality of life in adolescents with type 1 diabetes. Report from two Italian centres for the management of diabetes in childhood. Acta Biomed 2003;74(Suppl 1):13-17.

17. Ingerski LM, Laffel $L$, Drotar $D$, et al. Correlates of glycemic control and quality of life outcomes in adolescents with type 1 diabetes. Pediatr Diabetes 2010;11(8):563-571.

18. Puri K, Sapra S, Jain V. Emotional, behavioral and cognitive profile, and quality of life of Indian children and adolescents with type 1 diabetes. Indian J Endocrinol Metab 2013;17(6):1078-1083. 


\title{
QUALITY OF LIFE FOR INDIAN DIABETIC CHILDREN
}

\author{
(Modified QOLID Questionnaire)
}

(मधुमेह के रोग वाले भारतीय बच्चों मे जीवन की गुणवता का आंकलन करने के लिए प्नावली)

\section{Role Limitation Due to Physical Health/' Mfj j hd LokL;}

1. How often your child misses school because of diabetes?

मधुमेह के कारण कितनी बार आपका बच्चा स्कल नहीं जा पाता है?

\begin{tabular}{lllll}
\hline Always & Frequently & Often & Sometimes & Never \\
\hline हमेशा & काफी बार & यदाकदा & कभी कभी & कभी नहीं \\
1 & 2 & 3 & 4 & 5 \\
\hline
\end{tabular}

2. A person with diabetes has the requirement of adhering to a schedule for eating and taking regular medication. How often does this affect your child's school work or daily activities (playing)?

मधुमेह की बिमारी वाले बच्चों मे नियमित रूप से खानपान में सावधनी रखाने की आवश्यकता होती है?इसके कारण आपके बच्चे की दिनचर्या कितनी पभावित होती है?

\begin{tabular}{lllll}
\hline Always & Frequently & Often & Sometimes & Never \\
\hline हमेशा & काफी बार & यदाकदा & कभी कभी & कभी नहीं \\
1 & 2 & 3 & 4 & 5 \\
\hline
\end{tabular}

3. How often does diabetes affect your child's efficiency at school? मधुमेह के कारण आपके बच्चे की स्कूल के कार्य करने की क्षमता किस हद तक प्रभावित हुई है?

\begin{tabular}{lllll}
\hline Always & Frequently & Often & Sometimes & Never \\
\hline हमेशा & काफी बार & यदाकदा & कभी कभी & कभी नहीं \\
1 & 2 & 3 & 4 & 5 \\
\hline
\end{tabular}

4. How often do you find diabetes limiting your child's social life (interacting with friends)?

कितनी बार मधुमेह रोग के कारण आपका बच्चा सामाजिक क्रियाकलाप में भाग नहीं ले पाता?;दोस्ता से मिलना जुलनाद्ध

\begin{tabular}{lllll}
\hline Always & Frequently & Often & Sometimes & Never \\
\hline हमेशा & काफी बार & यदाकदा & कभी कभी & कभी नहीं \\
1 & 2 & 3 & 4 & 5 \\
\hline
\end{tabular}

5. To what extent does your child avoid travelling (picnics, outing with friends/relatives) because of diabetes?

मधुमेह के करण, आपका बच्चा किस हद तक सफर करना ;पिकनिक, पिक्चर देखने जाना, दोस्तों के साथ बाहर घुमनाद्ध टालता है?

\begin{tabular}{lllll}
\hline Always & Frequently & Often & Sometimes & Never \\
\hline हमेशा & काफी बार & यदाकदा & कभी कभी & कभी नहीं \\
1 & 2 & 3 & 4 & 5 \\
\hline
\end{tabular}

6. Compared to others of your child's age, are his/her social activities (visiting friends/ partying) limited because of diabetes? आपके बच्चे की उमर के और बच्चों की तुलना में आपके बच्चे के सामाजिक क्रियाकलप किस हद तक पभावित है?

\begin{tabular}{lllll}
\hline Always & Frequently & Often & Sometimes & Never \\
\hline हमेशा & काफी बार & यदाकदा & कभी कभी & कभी नहीं \\
1 & 2 & 3 & 4 & 5 \\
\hline
\end{tabular}

\section{Physical Endurance/' kij lfj d LFWf; Ro}

1. How often in last three months ha your child's overall health problem limited the kind of vigorous activities he/she can do like lifting heavy bags/objects, running, skipping, jumping? पिछले 3 महिनों में मधुमेह रोग के कारण कितनी बार आपके बच्चे को सश

\begin{tabular}{lllll}
\hline Always & Frequently & Often & Sometimes & Never \\
\hline हमेशा & काफी बार & यदाकदा & कभी कभी & कभी नहीं \\
1 & 2 & 3 & 4 & 5 \\
\hline
\end{tabular}

2. How often in last three months has your child's overall health problems limited the kind of moderate activities he/she can do like moving a table, carrying school bag?

पिछले २ महिनों में मधुमेह रोग के कारण कितनी बार आपके बच्चे को साधरण क्रियाकलाप करने में दिक्कत हुई?

\begin{tabular}{lllll}
\hline Always & Frequently & Often & Sometimes & Never \\
\hline हमेशा & काफी बार & यदाकदा & कभी कभी & कभी नहीं \\
1 & 2 & 3 & 4 & 5 \\
\hline
\end{tabular}

3. How often in last three months has your child's overall health problems limited him/her from walking uphill or climbing 1-2 floors?

पिछले 2 महिनों में मधुमेह रोग के कारण कितनी बार आपके बच्चों को चढाई करने पर/सिढ़िया चढने मे शिकायत हुई ?

\begin{tabular}{lllll}
\hline Always & Frequently & Often & Sometimes & Never \\
\hline हमेशा & काफी बार & यदाकदा & कभी कभी & कभी नहीं \\
1 & 2 & 3 & 4 & 5 \\
\hline
\end{tabular}

4. How often in last three months has your child's overall health problems limited him/her from walking 1-2 km at a stretch?

पिछले 2 महिनों में मधुमेह के कारण आपके बच्चे को एक बार में 1-2 एउ चलने में शिकायत हुई?

\begin{tabular}{lllll}
\hline Always & Frequently & Often & Sometimes & Never \\
\hline हमेशा & काफी बार & यदाकदा & कभी कभी & कभी नहीं \\
1 & 2 & 3 & 4 & 5 \\
\hline
\end{tabular}

5. How often in last three months has your child's overall health problems limited him/her from bending, squatting, or turning? पिछले 2 महिनों में आपके बच्चे को भुकना, आलथी पालथी मारने में दिक्कत हुई?

\begin{tabular}{lllll}
\hline Always & Frequently & Often & Sometimes & Never \\
\hline हमेशा & काफी बार & यदाकदा & कभी कभी & कभी नहीं \\
1 & 2 & 3 & 4 & 5
\end{tabular}

6. How often in last three months has your child's overall health problems limited him/her from eating, dressing, bathing, or using the toilet?

पिछले 2 महिनों में आपके बच्चे को दैनिक क्रियाकलाप करना ;जैसे खाना/कपड़े पहनाना/नहाना/शौचालय जानेद्ध में दिक्कत हुई?

\begin{tabular}{lllll}
\hline Always & Frequently & Often & Sometimes & Never \\
\hline हमेशा & काफी बार & यदाकदा & कभी कभी & कभी नहीं \\
1 & 2 & 3 & 4 & 5 \\
\hline
\end{tabular}




\section{General Health/I koz fud Lokf;}

1. In general would you say your child's health is? सामान्य रूप में/आपके विचार मे आपका बच्चे का स्वास्थ्य कैसा है?

\begin{tabular}{lllll}
\hline Always & Frequently & Often & Sometimes & Never \\
\hline हमेशा & काफी बार & यदाकदा & कभी कभी & कभी नहीं \\
1 & 2 & 3 & 4 & 5 \\
\hline
\end{tabular}

2. How well is your child able to concentrate in studying, playing, reading etc?

आपके विचार में आपका बच्चा पढाई/स्कुल में किस हद तक ध्यान केन्द्रित कर पाता है?

\begin{tabular}{lllll}
\hline Always & Frequently & Often & Sometimes & Never \\
\hline हमेशा & काफी बार & यदाकदा & कभी कभी & कभी नहीं \\
1 & 2 & 3 & 4 & 5
\end{tabular}

3. How many times in the past three months has your child had fatigue/felt very tired?

पिछले 2 महिनों में मधुमेह रोग के कारण आपके बच्चे को कितनी बार थकावट महस ${ }_{n}$ स हुई है?

\begin{tabular}{lllll}
\hline Always & Frequently & Often & Sometimes & Never \\
\hline हमेशा & काफी बार & यदाकदा & कभी कभी & कभी नहीं \\
1 & 2 & 3 & 4 & 5 \\
\hline
\end{tabular}

\section{Treatment Satisfaction/ mi plj I Ur fq V}

The following set of questions would enable us to know how satisfied are you with your child's treatment for diabetes. Please tick any one option.

1. How satisfied are you with your child's current diabetes treatment?

आप अपने बच्चे के वर्तमान में चल रहे मधुमेह के इलाज से कितना सन्तुष्ट हो?

\begin{tabular}{lllll}
\hline $\begin{array}{l}\text { Very } \\
\text { dissatisfied }\end{array}$ & $\begin{array}{l}\text { Moderately } \\
\text { dissatisfied }\end{array}$ & $\begin{array}{l}\text { Neither } \\
\text { satisfied nor } \\
\text { dissatisfied }\end{array}$ & $\begin{array}{l}\text { Moderately } \\
\text { satisfied }\end{array}$ & $\begin{array}{l}\text { Very } \\
\text { satisfied }\end{array}$ \\
\hline बहुत असन्तुष्ट & असन्तुष्ट & $\begin{array}{l}\text { न सन्तुष्ट/न } \\
\text { असन्तुष्ट सन्तुष्ट }\end{array}$ & बहुत सन्तुष्ट & \\
1 & 2 & 3 & 4 & 5
\end{tabular}

2. How satisfied are you with amount of time it takes to manage your child's diabetes?

आप आपने बच्चे के महुमेह के इलाज पर बिताये जा रह/व्यतीत हो रहे समय से कितना सन्तुष्ट हो?

\begin{tabular}{lllll}
\hline $\begin{array}{l}\text { Very } \\
\text { dissatisfied }\end{array}$ & $\begin{array}{l}\text { Moderately } \\
\text { dissatisfied }\end{array}$ & $\begin{array}{l}\text { Neither } \\
\text { satisfied nor } \\
\text { dissatisfied }\end{array}$ & $\begin{array}{l}\text { Moderately } \\
\text { satisfied }\end{array}$ & $\begin{array}{l}\text { Very } \\
\text { satisfied }\end{array}$ \\
\hline बहुत असन्तुष्ट & असन्तुष्ट & $\begin{array}{l}\text { न सन्तुष्ट/न } \\
\text { असन्तुष्ट सन्तुष्ट }\end{array}$ & बहुत सन्तुष्ट & \\
1 & 2 & 3 & 4 & 5 \\
\hline
\end{tabular}

3. How satisfied are you with the amount of time you spend getting regular checkups for your child (once in 3 months)?

आप अपने बच्चे के मधुमेह के इलाज के लिए नियमित जाँच कराने के में लगने वाले समय से कितना सन्तुष्ट हो?

\begin{tabular}{lllll}
\hline $\begin{array}{l}\text { Very } \\
\text { dissatisfied }\end{array}$ & $\begin{array}{l}\text { Moderately } \\
\text { dissatisfied }\end{array}$ & $\begin{array}{l}\text { Neither } \\
\text { satisfied nor } \\
\text { dissatisfied }\end{array}$ & $\begin{array}{l}\text { Moderately } \\
\text { satisfied }\end{array}$ & $\begin{array}{l}\text { Very } \\
\text { satisfied }\end{array}$ \\
\hline बहुत असन्तुष्ट & असन्तुष्ट & $\begin{array}{l}\text { न सन्तुष्ट /न } \\
\text { असन्तुष्ट सन्तुष्ट }\end{array}$ & बहुत सन्तुष्ट & \\
1 & 2 & 3 & 4 & 5 \\
\hline
\end{tabular}

4. A person with diabetes needs to exercise for $35-45 \mathrm{~min}, 4$ times a week. Keeping this in mind how satisfied are you with the time your child spends exercising?

मधुमेह रोग वाले मरिजों को नियमित व्यायामक "करने कि आवश्यकता है; 30-45 उपदए $4 / \Omega$ द्ध इसे ध्यान में रखने हुए व्यायाम में बिताए जा रहे समय से आप कितने सन्तुष्ट हो?

\begin{tabular}{lllll}
\hline $\begin{array}{l}\text { Very } \\
\text { dissatisfied }\end{array}$ & $\begin{array}{l}\text { Moderately } \\
\text { dissatisfied }\end{array}$ & $\begin{array}{l}\text { Neither } \\
\text { satisfied nor } \\
\text { dissatisfied }\end{array}$ & $\begin{array}{l}\text { Moderately } \\
\text { satisfied }\end{array}$ & $\begin{array}{l}\text { Very } \\
\text { satisfied }\end{array}$ \\
\hline बहुत असन्तुष्ट & असन्तुष्ट & $\begin{array}{l}\text { न सन्तुष्ट /न } \\
\text { असन्तुष्ट सन्तुष्ट }\end{array}$ & बहुत सन्तुष्ट & \\
1 & 2 & 3 & 4 & 5 \\
\hline
\end{tabular}

\section{Symptom Botherness/jk d sy $\{k \mathrm{k} \mid$ si $j$ kkuh}

1. How many times in the past three months has your child had thirst/dry mouth?

पिछले 3 महिनों में आपके बच्चे को कितनी बार मुँह सुखना/प्यास लगने के लक्षण हुए है?

\begin{tabular}{lllll}
\hline Always & Frequently & Often & Sometimes & Never \\
\hline हमेशा & काफी बार & यदाकदा & कभी कभी & कभी नहीं \\
1 & 2 & 3 & 4 & 5
\end{tabular}

2. How many times in the past three months has your child felt excessive hunger?

पिछले 3 महिनों में आपके बच्चे को कितनी बार बहुत ज्यादा भ ख लगने के लक्ष्ण हुए है?

\begin{tabular}{lllll}
\hline Always & Frequently & Often & Sometimes & Never \\
\hline हमेशा & काफी बार & यदाकदा & कभी कभी & कभी नहीं \\
1 & 2 & 3 & 4 & 5 \\
\hline
\end{tabular}

3. How many times in the past three months has your child had frequent urination related to diabetes management?

पिछले 3 महिनों में आपके बच्चे को कितनी बार बारबार पैशाब जाने के लक्षण हुए है?

\begin{tabular}{lllll}
\hline Always & Frequently & Often & Sometimes & Never \\
\hline हमेशा & काफी बार & यदाकदा & कभी कभी & कभी नहीं \\
1 & 2 & 3 & 4 & 5 \\
\hline
\end{tabular}

\section{Financial Worries/v IfFk $f p$ Ur k}

1. What do you think about the cost involved in management of your child's diabetes?

आपके बच्चे के महुमेह रोग के इलाज के खर्चे के बारे में आप क्या सोचते हो?

\begin{tabular}{lllll}
\hline Always & Frequently & Often & Sometimes & Never \\
\hline हमेशा & काफी बार & यदाकदा & कभी कभी & कभी नहीं \\
1 & 2 & 3 & 4 & 5
\end{tabular}

2. To what extent has your priority of expenditure shifted towards diabetes management?

किस हद तक आपके खर्चे को पाथमिकता मधुमेह रोग के इलाज की तरफ बद गई है? ;भुकाव आया हैद्ध

\begin{tabular}{lllll}
\hline Always & Frequently & Often & Sometimes & Never \\
\hline हमेशा & काफी बार & यदाकदा & कभी कभी & कभी नहीं \\
1 & 2 & 3 & 4 & 5 \\
\hline
\end{tabular}


Quality of Life for Indian Diabetic Children

3. To what extent has your family budget got affected by the expenses related to the management of diabetes?

आपके बच्चे के मधुमेह के इलाज के कारण आपका परिवार का मासिक खर्च किस हद तक पभावित हुआ है?

\begin{tabular}{lllll}
\hline Always & Frequently & Often & Sometimes & Never \\
\hline हमेशा & काफी बार & यदाकदा & कभी कभी & कभी नहीं \\
1 & 2 & 3 & 4 & 5 \\
\hline
\end{tabular}

4. To what extent has your diabetes limited your expenditure on other aspects of life (Movies, outings, parties etc)?

आपके बच्चे के मधुमेह के इलाज के कारण किस इद तक आपके जीवन के अन्य पहलुओं के खर्च पर असर हुआ है?

\begin{tabular}{lllll}
\hline Always & Frequently & Often & Sometimes & Never \\
\hline हमेशा & काफी बार & यदाकदा & कभी कभी & कभी नहीं \\
1 & 2 & 3 & 4 & 5 \\
\hline
\end{tabular}

\section{Emotional/Mental Health/ e kufl d @ HkokPed LokLF;}

1. How satisfied are you with your child? आप अपने बच्चे से कितना सन्तुष्ट हो?

\begin{tabular}{lllll}
\hline $\begin{array}{l}\text { Very } \\
\text { dissatisfied }\end{array}$ & $\begin{array}{l}\text { Moderately } \\
\text { dissatisfied }\end{array}$ & $\begin{array}{l}\text { Neither } \\
\text { satisfied nor } \\
\text { dissatisfied }\end{array}$ & $\begin{array}{l}\text { Moderately } \\
\text { satisfied }\end{array}$ & $\begin{array}{l}\text { Very } \\
\text { satisfied }\end{array}$ \\
\hline बहुत असन्तुष्ट & असन्तुष्ट & $\begin{array}{l}\text { न सन्तुष्ट /न } \\
\text { असन्तुष्ट }\end{array}$ & सन्तुष्ट & $\begin{array}{l}\text { बहुत } \\
\text { सन्तुष्ट }\end{array}$ \\
1 & 2 & 3 & 4 & 5 \\
\hline
\end{tabular}

2. How satisfied are you with your child's personal relationships (family, friends, relatives )?

आप अपने बच्चे के व्यक्तिगत/वयवहारिक सम्बन्धों से कितना सन्तुष्ट हो ;पारिवारिक, दोस्तों द्ध ह

\begin{tabular}{lllll}
\hline $\begin{array}{l}\text { Very } \\
\text { dissatisfied }\end{array}$ & $\begin{array}{l}\text { Moderately } \\
\text { dissatisfied }\end{array}$ & $\begin{array}{l}\text { Neither } \\
\text { satisfied nor } \\
\text { dissatisfied }\end{array}$ & $\begin{array}{l}\text { Moderately } \\
\text { satisfied }\end{array}$ & $\begin{array}{l}\text { Very } \\
\text { satisfied }\end{array}$ \\
\hline बहुत असन्तुष्ट & असन्तुष्ट & $\begin{array}{l}\text { न सन्तुष्ट/न } \\
\text { असन्तुष्ट }\end{array}$ & सन्तुष्ट & $\begin{array}{l}\text { बहुत } \\
\text { सन्तुष्ट }\end{array}$ \\
1 & 2 & 3 & 4 & 5 \\
\hline
\end{tabular}

3. How satisfied are you with the emotional support your child gets from his/her friends and family?

आप अपने बच्चो को परिवार व दोस्तो से मिले भावुक/भावनात्मक सहारे से कितना सन्तुष्ट हो?

\begin{tabular}{lllll}
\hline $\begin{array}{l}\text { Very } \\
\text { dissatisfied }\end{array}$ & $\begin{array}{l}\text { Moderately } \\
\text { dissatisfied }\end{array}$ & $\begin{array}{l}\text { Neither } \\
\text { satisfied nor } \\
\text { dissatisfied }\end{array}$ & $\begin{array}{l}\text { Moderately } \\
\text { satisfied }\end{array}$ & $\begin{array}{l}\text { Very } \\
\text { satisfied }\end{array}$ \\
\hline बहुत असन्तुष्ट & असन्तुष्ट & $\begin{array}{l}\text { न सन्तुष्ट /न } \\
\text { असन्तुष्ट }\end{array}$ & सन्तुष्ट & $\begin{array}{l}\text { बहुत } \\
\text { सन्तुष्ट }\end{array}$ \\
1 & 2 & 3 & 4 & 5 \\
\hline
\end{tabular}

4. How often is your child discouraged by his/her health problems? आपका बच्चा अपने स्वास्थ्य के कारण कितनी बार निराश हुआ है?

\begin{tabular}{lllll}
\hline $\begin{array}{l}\text { Very } \\
\text { dissatisfied }\end{array}$ & $\begin{array}{l}\text { Moderately } \\
\text { dissatisfied }\end{array}$ & $\begin{array}{l}\text { Neither } \\
\text { satisfied nor } \\
\text { dissatisfied }\end{array}$ & $\begin{array}{l}\text { Moderately } \\
\text { satisfied }\end{array}$ & $\begin{array}{l}\text { Very } \\
\text { satisfied }\end{array}$ \\
\hline बहुत असन्तुष्ट & असन्तुष्ट & $\begin{array}{l}\text { न सन्तुष्ट/न } \\
\text { असन्तुष्ट }\end{array}$ & सन्तुष्ट & $\begin{array}{l}\text { बहुत } \\
\text { सन्तुष्ट }\end{array}$ \\
1 & 2 & 3 & 4 & 5 \\
\hline
\end{tabular}

5. All people want to fulfill certain roles and lead their lives in a purposeful manner. To what extent do you feel that your child has been able to lead your life in the same way? आपका बच्चा किस हद तक अपने जीवन को उदेश्यप र्ण तरीके से जाने में समर्थ है?

\begin{tabular}{lllll}
\hline $\begin{array}{l}\text { Very } \\
\text { dissatisfied }\end{array}$ & $\begin{array}{l}\text { Moderately } \\
\text { dissatisfied }\end{array}$ & $\begin{array}{l}\text { Natisfied nor } \\
\text { dissatisfied }\end{array}$ & $\begin{array}{l}\text { Moderately } \\
\text { satisfied }\end{array}$ & $\begin{array}{l}\text { Very } \\
\text { satisfied }\end{array}$ \\
\hline बहुत असन्तुष्ट & असन्तुष्ट & $\begin{array}{l}\text { न सन्तुष्ट /न } \\
\text { असन्तुष्ट }\end{array}$ & सन्तुष्ट & $\begin{array}{l}\text { बहुत } \\
\text { सन्तुष्ट }\end{array}$ \\
1 & 2 & 3 & 4 & 5 \\
\hline
\end{tabular}

\section{Diet Satisfaction/ v kg kj I ur f'V}

1. How often does your child feel because of diabetes a restriction in choosing food when eating out?

कितनी बार आपके बच्चों को बाहर खाने में अपना पंसद का खाना चुनने मे पाबंदी महस ${ }_{0}$ स होती है?

\begin{tabular}{lllll}
\hline Always & Frequently & Often & Sometimes & Never \\
\hline हमेशा & काफी बार & यदाकदा & कभी कभी & कभी नहीं \\
1 & 2 & 3 & 4 & 5 \\
\hline
\end{tabular}

2. As your child has diabetes, how much choice do you feel your child has in eating his/her meals or snacks away from home e.g in a party where there are also a lot of fried snacks and desserts would he/she be able to make enough choice?

घर के बाहर खाना खाने में आपके बचचे के पास कितने विक्लप होते है?

\begin{tabular}{lllll}
\hline Always & Frequently & Often & Sometimes & Never \\
\hline हमेशा & काफी बार & यदाकदा & कभी कभी & कभी नहीं \\
1 & 2 & 3 & 4 & 5 \\
\hline
\end{tabular}

3. How often does your child eat the food items that he/she shouldn't?

मधुमेह रोग ;को छुपाने के लिएद्ध के कारण कितनी बार आपके बच्चों को वह खाना पड़ता है जो उसे नहीं खाना चाहिए?

\begin{tabular}{lllll}
\hline Always & Frequently & Often & Sometimes & Never \\
\hline हमेशा & काफी बार & यदाकदा & कभी कभी & कभी नहीं \\
1 & 2 & 3 & 4 & 5 \\
\hline
\end{tabular}

4. How would you rate the overall quality of life of your child? कुल मिलाकर आप अपने बच्चे के समस्त जीवन की गुणवता को कैसे आंकते हो?

\begin{tabular}{lllll}
\hline Poor & Average & Good & Very good & Excellent \\
\hline खराब & औसतम & अच्छा & बहुत अच्छा & सर्वोत्तम \\
1 & 2 & 3 & 4 & 5 \\
\hline
\end{tabular}

